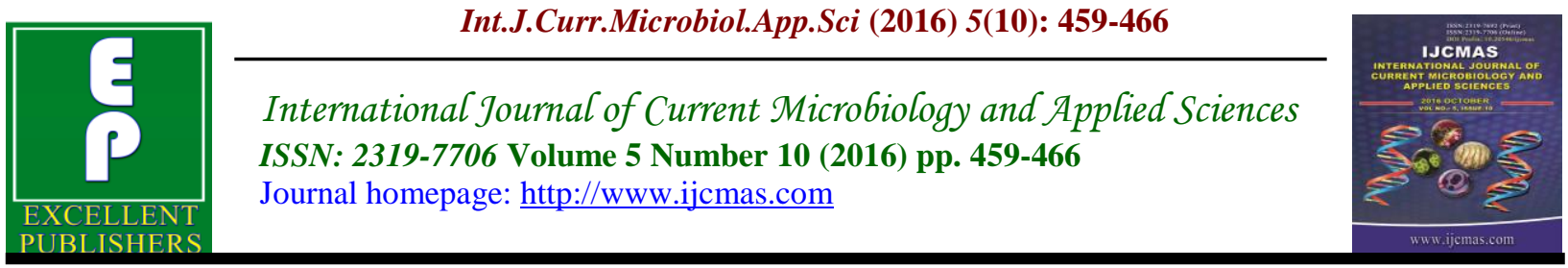

Original Research Article

http://dx.doi.org/10.20546/ijcmas.2016.510.052

\title{
Characterization of Alternaria alternata Isolated from Calotropis gigantea Plant Leaf
}

\author{
Prabhat Kumar Mishra* and Vijay Thawani \\ Centre for Scientific Research and Development, \\ People's University, Bhanpur Bhopal - 462037 (Madhya Pradesh) India \\ *Corresponding author
}

Keywords

$\mathrm{pH}$,

temperature, media,

cultural

characteristics.

\section{Article Info}

Accepted:

17 September 2016

Available Online:

10 October 2016

\section{A B S T R A C T}

Calotropis (madar) is used as a traditional medicine either alone or with other actives in the treatment of fever, rheumatism, indigestion, cough, cold, eczema, asthma, elephantiasis, nausea, vomiting, and diarrhea. In Ayurveda the dried whole plant is recommended as a tonic, expectorant, depurative, harbs and anitparasitic. The dried root bark is a substitute for vomiting. The flowers are bitter, digestive, astringent, stomachic, anthelmintic, vermicide and tonic. Alternaria alternata isolated from Calotropis gigantea showed excellent growth in potato carrot agar (PCA) medium with a colony diameter of $2 \mathrm{~cm}$ after 4 days of incubation at $27^{\circ} \mathrm{C}$ for 8 days and declined from $11^{\text {th }}$ day of incubation. Alternaria alternata favoured slightly acidic and neutral ph range while poor mycelia development was observed in alkaline medium. At alkaline ph, hydrogen ion concentration had inhibitory effect on the growth and development of mycelia and pigmentation of the fungus. Alternaria alternata could grow at a wide range of temperature between $20-30^{\circ} \mathrm{C}$. Best growth and sporulation of the fungus was observed at $27^{\circ} \mathrm{C}$, with colony diameter of $2.6 \mathrm{cms}$ and sporulation. At $27^{\circ} \mathrm{C}$, the colony diameter was $2.6 \mathrm{~cm}$ and sporulation was good. The fungus attained its best growth and sporulation at 95 and $100 \% \mathrm{RH}$, with colony diameter measuring 2.6 and $2.9 \mathrm{~cm}$ respectively. Alternaria alternata appears from June to August at temperature of 25 to $30^{\circ} \mathrm{C}$.

\section{Introduction}

Calotropis gigantea is a large shrub growing to $4 \mathrm{~m}$ height, having clusters of white or lavender coloured waxy flowers. Each flower consists of five pointed petals and a small, elegant "crown" rising from the centre, which holds the stamens. The plant has oval, light green leaves and milky stem. The latex of Calotropis gigantea contains cardiac glycosides, fatty acids, and calcium oxalate. There may be at least one million species of endophytic fungi. Recently these have received attention after these were found to protect their host against insects, pests, and pathogens. Blight symptoms on pigeon pea were found in Andhra Pradesh since 2009 (Sharma et al., 2013). Alternaria alternata was reported in soyabean plants (Shrikant et al., 2014). Some fungicide was important for Alternaria alternate (Hege et al., 2015). 


\section{Material and Methods}

\section{Collection of plant samples}

Stems, leaves and flowers of Calotropis gigantea were collected from different areas of Bhopal region. Healthy and mature plant leaves were chosen for sampling and kept in box containing ice cubes.

\section{Isolation of endophytic fungus}

The samples were rinsed gently in running tap water to remove dust and debris. The stem leaves (lateral and midrib) and flowers were cut into segments $(0.5-1 \mathrm{~cm})$. The samples were surface sterilized by modified method (Deshmukh, 1998). The samples were immersed in $70 \%$ ethanol for $5 \mathrm{~s}$, followed by $4 \%$ sodium hypochlorite for 90 s and then rinsed in sterile distilled water for 10s. The excess moisture was blotted in a sterile filter paper. The surface sterilized segments were placed in Petri dishes containing PDA medium. The Petri dishes were sealed with para film and incubated at $27^{\circ} \mathrm{C}$ at $12 \mathrm{~h}$ light/dark cycle. The Petri dishes were monitored every day to check the growth of endophytic fungal colonies from the segments.

Koch's Postulates were completed by spraying 75-day-old healthy Calotropis gigantea plant leaves with an aqueous spore suspension of $1 \times 10^{6}$ conidia per $\mathrm{ml}$ in evening. Inoculated plants were placed in an environmental chamber at $23^{\circ} \mathrm{C}$ with $8 \mathrm{~h}$ of daily light and $75 \%$ relative humidity for $48 \mathrm{~h}$. Then inoculated and non inoculated plants were moved to a $25^{\circ} \mathrm{C}$ green house and watered twice a day. Leaf spots initially appeared on the upper surface of older leaves after 7 days and by 12-15 days, leaf spots developed on every inoculated plant. No symptoms developed on plants sprayed with distilled water. A. alternata was consistently re-isolated from the inoculated plants.

\section{Identification and diagnosis}

Slide culture technique was used for the identification of different isolates of $A$. alternate (Deshmukh, 1998) on the basis of morphological characteristics. For this sterilized moist chamber was prepared by keeping thin cotton pad, a wet filter paper and a slide inside a sterilized Petri plate. Saboraud dextrose agar medium was prepared and poured on a sterilized glass plate as a thin film. After solidification, this film was cut into small cubes with flamed scalpel. These cubes were placed on slides inside the moist chambers and inoculated with fungal spores. These slide cultures were incubated at $28^{\circ} \mathrm{C}$ in a BOD incubator. After sporulation, the slides were stained with cotton blue, mounted in lactophenol and were observed for identification. For permanent mounts stained DPX fungal identification was done on the basis of morphotaxonomic characters. Microscopic examination was done to ensure that the cultures were not mixed. Homogenous fungal culture was obtained by spreading 0.1 $\mathrm{ml}$ spore suspension, containing $1 \times 10^{6}$ spores per $\mathrm{ml}$ in water with $0.05 \%$ Tween 80 , applied evenly onto the PDA medium in Petri dishes incubated at $28 \pm 1^{\circ} \mathrm{C}$ in the dark. After two days mycelium plugs were removed with a sterile cork borer and transferred to Petri dishes with either Potato Dextrose Agar (PDA), Potato Carrot Agar (PCA), Maltose Extract Peptone agar (MEP), Sabourad Maltose Yeast (SMY) extract agar, Sabouraud Dextose Agar (SDA), Coon's, Czapek's, Richards or casein agar media with different potentials. Measurements of the mycelia growth was done after three to six days of incubation at $27 \pm 1^{0}$ Celsius (C). The diameter of the colonies was estimated by calculating the mean of two perpendicular measurements. The sporulation rate was assessed after six days. The Petri dishes were rinsed with $1 \mathrm{ml}$ 
of Tween 80 and the conidia were scraped with a spatula. The spore concentration was determined with a haemocytometer and the viability of the conidia was examined after incubation for $24 \mathrm{~h}$ at $28 \pm 1^{0} \mathrm{C}$ on SDA.

\section{Growth pattern of $A$. alternate}

Conical flasks containing $25 \mathrm{ml} \mathrm{SD}$ broth in each were inoculated with $1 \mathrm{ml}$ of conidial suspension of A. alternata and were incubated at $28 \pm 1^{0} \mathrm{C}$. The dry weights of mycelia were taken from 2 to 15 days of incubation.

\section{Determination of an effective growth of A. alternate}

$40 \mathrm{ml}$ of SDA medium of ph gradient from 2 to12 was prepared and sterilized and the autoclaved medium was poured in pre sterilized Petri plates. After solidification of the medium, plates were spot inoculated with $A$. alternate. The inoculated plates were maintained at $28 \pm 1^{0} \mathrm{C}$. The colony diameter and characteristics were observed daily after an incubation period of $48 \mathrm{~h}$.

Evaluation of mycelial growth and spore production of $A$. alternate homogenous fungal culture was obtained by spreading 0.1 $\mathrm{ml}$ spore suspension, containing $10^{6}$ spores per $\mathrm{ml}$ in water with $0.05 \%$ Tween 80, evenly onto PDA Medium in Petri dishes $(9 \mathrm{~cm})$. The Petri dishes were incubated at $27 \pm 1^{\circ} \mathrm{C}$ in the dark. After two days, mycelium plugs were removed with a sterile cork borer $(0.6 \mathrm{~cm})$ and transferred to Petri dishes with either PDA, PCA, MEP, SMY, SDA, Coon's, Zapek's, Richard's and Casein agar media, with different water potentials. Measurement of the mycelial growth was done after three and six days of incubation at $27 \pm 1^{0} \mathrm{C}$. The diameter of colonies was estimated by calculating the mean of two perpendicular measurements.
The sporulation rate was assessed after six days. The Petri dishes were rinsed with $1 \mathrm{ml}$ of Tween 80 and the conidia were scraped off with a spatula. The spore concentration was determined with haemocytometer and the viability of the conidia was examined after incubation for $24 \mathrm{~h}$ at $27 \pm 1^{\circ} \mathrm{C}$ on SDA.

\section{Effect of different temperatures on the growth of $A$. alternate}

The method of Sandhu (Sandhu, 1995) was followed. Inoculated Petri plates were incubated at different temperature viz. 5, 10, 15, 20, 25, 28, 30, 35 and $40^{\circ} \mathrm{C}$ and observations recorded after seven days of incubation.

\section{Effect of different relative humidity on the growth of $A$. alternate}

Effect of different relative humidity on the growth and sporulation of A. alternate was observed on solidified Sabouraud's maltose medium, supplemented with $1 \%$ yeast extract. Inoculated Petri plates were incubated at relative humidity of $53,75,85$, 95 , and $100 \%$. Observations were recorded after seven days of incubation.

\section{Result and Discussion}

In the lab this fungus grew on almost all the tested media with differential growth patterns. This experiment was conducted to select the best suitable medium for the growth of $A$. alternata. The growth on different media was measured by taking the diameter of the colony after four days of incubation, because radial increase in the colony is the only reliable characteristic for measuring growth on different solid media, as it can be measured repeatedly. The best growth was observed on PCA medium with colony diameter of $2 \mathrm{cms}$ after four days of incubation. [Table 1] 


\section{Growth pattern of A. alternata}

Growth is considered as an irreversible increase in the mass/volume of an organism that occurs after a given period of incubation, in nature or in laboratory. Growth curve test was done to get the juvenile growth stage of fungal mycelia. It is necessary to consider vegetative growth in fungi separately as it exhibits different modes or pattern of growth. The Table 2 shows that the stationary phase of growth of A. alternata occurred from eighth day with the decline phase starting from the $11^{\text {th }}$ day of incubation.

\section{Effect of hydrogen ion concentration or ph on the growth of A. alternate}

Environmental factors greatly influence the behavior of fungi. Under natural conditions, fungi obtain all their requirements from the host of substratum for the synthesis of their cell constituents and also for the operation of their life process. The A. alternata favors slightly acidic as well as neutral ph range while poor mycelia development was observed in alkaline medium. At alkaline ph, hydrogen ion concentration had inhibitory effect on the growth and development of mycelia and pigmentation of the fungus. Since change in the ph of a medium changes its composition if it contains weakly ionized constituents, the physiological effects of dissociated and undissociated species were different. Most of the fungi grow within the ph range 4-8, many fungi grow over a wider range, and few have been reported to have a narrower range. [Table 3]

\section{Effect of different temperatures on the growth of A. alternata}

Temperature is an important factor affecting the natural activity of entophytic fungi and the importance of favorable temperature for the optimal growth of endophytic fungi has been mentioned. Much information is available on the effect of temperature on growth of fungi in vitro (Ferron, 1978). Generally, the limit for growth ranges between $5-35^{\circ} \mathrm{C}$ and optimal fall between 20 and $30^{\circ} \mathrm{C}$. The influence of temperature and relative humidity on fungi on rapidity of mycelia development has been studied. It was observed that $A$. alternate could grow at a wide range of temperature between $20-35^{0}$ C.

Table.1 Effect of different of media on the growth of Alternaria alternate

\begin{tabular}{|l|c|}
\hline Name of Media & $\begin{array}{l}\text { Colony diameter (CMS) } \\
\text { After 4 days of incubation }\end{array}$ \\
\hline Sabouraud Dexotose Agar & 1.9 \\
\hline Sabourad Maltose Yeast extract agar & 1.8 \\
\hline Potato Dextose Agar & 1.8 \\
\hline Potato carrot agar & 2.0 \\
\hline RICHARD'S & 1.7 \\
\hline CASEIN AGAR & 0.9 \\
\hline COON'S & 1.1 \\
\hline CZAPEK'S & 1.0 \\
\hline Malt Extract Peptone agar & 1.0 \\
\hline
\end{tabular}


Table.2 Effect of different media on the growth of Alternaria alternate

\begin{tabular}{|l|l|l|l|}
\hline $\begin{array}{l}\text { Days of Table } \\
\text { incubation }\end{array}$ & $\begin{array}{l}\text { A- Weight of } \\
\text { filter paper (g) }\end{array}$ & $\begin{array}{l}\text { B- Weight of filter } \\
\text { paper and mycelia }\end{array}$ & $\begin{array}{l}\text { C= B-A Weight of } \\
\text { mycelia }\end{array}$ \\
\hline 1 & 0.453 & 0.598 & 0.145 \\
\hline 2 & 0.388 & 0.550 & 0.162 \\
\hline 3 & 0.435 & 0.618 & 0.183 \\
\hline 4 & 1.107 & 1.292 & 0.185 \\
\hline 5 & 0.996 & 1.216 & 0.220 \\
\hline 6 & 0.961 & 1.236 & 0.275 \\
\hline 7 & 1.014 & 1.330 & 0.316 \\
\hline 8 & 0.650 & 1.130 & 0.480 \\
\hline 9 & 0.971 & 1.448 & 0.477 \\
\hline 10 & 0.812 & 1.288 & 0.476 \\
\hline 11 & 0.558 & 1.031 & 0.473 \\
\hline 12 & 0.817 & 1.203 & 0.386 \\
\hline 13 & 0.567 & 0.852 & 0.285 \\
\hline 14 & 0.616 & 0.887 & 0.271 \\
\hline
\end{tabular}

Table.3 Effect of hydrogen ion concentration on the growth of Alternaria alternate

\begin{tabular}{|l|l|l|}
\hline $\mathrm{pH}$ & $\begin{array}{l}\text { Colony } \\
\text { diameter } \\
\text { (in cms) }\end{array}$ & Colony characteristics \\
\hline 2 & Nill & No growth \\
\hline 3 & Nill & No growth \\
\hline 4 & 1.0 & Thick, brownish color change in greenish colony with elevation at the centre \\
\hline 5 & 2.2 & $\begin{array}{l}\text { Thick, brownish color changes in slightly greenish colony with elevation at the } \\
\text { centre. }\end{array}$ \\
\hline 6 & 2.7 & Thick, brownish colony with elevation at the centre color changes in green \\
\hline 7 & 2.4 & Thin, brownish cotton colony to greenish \\
\hline 8 & 3.1 & Thin, brownish cotton colony to greenish \\
\hline 9 & 1.8 & Thin, brownish cotton colony \\
\hline 10 & 1.8 & Brownish colony \\
\hline 11 & 1.8 & Brownish colony \\
\hline 12 & 1.8 & Brownish colony \\
\hline
\end{tabular}


Table.4 Effect of different temperatures on the growth of Alternaria alternate

\begin{tabular}{|c|c|c|c|c|}
\hline Temperature & $\begin{array}{l}\text { Colony } \\
\text { diameter in } \mathrm{cm}\end{array}$ & Sporulation & $\begin{array}{l}\text { Spore } \\
\text { count } / \mathrm{ml}\end{array}$ & Characteristics \\
\hline 5 & 01 & Poor & 1020 & $\begin{array}{l}\text { Inoculum started } \\
\text { rooting only color initially brownish } \\
\text { and changes to green }\end{array}$ \\
\hline 10 & 0.2 & Poor & 1070 & $\begin{array}{l}\text { Inoculum started rooting with few } \\
\text { vegetative brownish mycelial growths } \\
\text { to green }\end{array}$ \\
\hline 15 & 0.4 & Poor & 1080 & $\begin{array}{l}\text { Growth colour was initially brownish } \\
\text { with good mycelia to slightly green }\end{array}$ \\
\hline 20 & 1.8 & Poor & 3050 & $\begin{array}{l}\text { Brownish colony, floccose powdery, } \\
\text { some pale droplets were present to } \\
\text { greenish }\end{array}$ \\
\hline 25 & 2.3 & Good & 5350 & Brownish colony to greenish \\
\hline 27 & 2.6 & Excellent & 6600 & Brownish colony, to greenish \\
\hline 30 & 2.5 & Good & 5700 & $\begin{array}{l}\text { Colony, white } \\
\text { Brownish in reverse side to greenish }\end{array}$ \\
\hline 35 & 0.4 & Poor & 1070 & $\begin{array}{l}\text { Brownish small colony with mycelia to } \\
\text { greenish }\end{array}$ \\
\hline 40 & 0.1 & No Growth & $\begin{array}{l}\text { No } \\
\text { Growth }\end{array}$ & No Growth \\
\hline $\begin{array}{l}\text { Room } \\
\text { Tem }-41\end{array}$ & No growth & No growth & $\begin{array}{l}\text { No } \\
\text { Growth }\end{array}$ & No Growth \\
\hline
\end{tabular}

Table.5 Effect of relative humidity on the growth of Alternaria alternate

\begin{tabular}{|l|l|l|l|l|}
\hline $\begin{array}{l}\text { Relative } \\
\text { Humidity }\end{array}$ & $\begin{array}{l}\text { Colony } \\
\text { diameter in } \\
\mathrm{cm}\end{array}$ & Sporulation & Spore count/ml & Colony Characteristics \\
\hline 53 & 1.6 & Moderate & $1.3 \times 10^{4}$ & $\begin{array}{l}\text { Colour was initially Brownish } \\
\text { and became green. Colony } \\
\text { brown on reverse side. }\end{array}$ \\
\hline 75 & 1.8 & Good & $0.95 \times 10^{5}$ & $\begin{array}{l}\text { Colony was initially Brownish } \\
\text { and become green. Brown on } \\
\text { reverse side. }\end{array}$ \\
\hline 85 & 2.0 & Good & $1 \times 10^{5}$ & $\begin{array}{l}\text { Brown initially, and reverse } \\
\text { slightly brown. }\end{array}$ \\
\hline 95 & 2.6 & Excellent & $1.5 \times 10^{5}$ & $\begin{array}{l}\text { Brown and slightly brown on } \\
\text { reverse side. }\end{array}$ \\
\hline 100 & 2.9 & Excellent & $1.45 \times 10^{5}$ & $\begin{array}{l}\text { Brown colony, brown on } \\
\text { reverse side. }\end{array}$ \\
\hline
\end{tabular}


The best growth and sporulation of the fungus were observed at $28-30^{\circ} \mathrm{C}$, as exhibited by colony diameter i.e. 2.6 and 2.5 $\mathrm{cm}$ and sporulation. At $25^{\circ} \mathrm{C}$, the colony diameter was $2.3 \mathrm{~cm}$ and sporulation was good. Colony characteristics were similar, except that much flosses growth and plate droplets were visible in sprouting colony at 25,28 and $30^{\circ} \mathrm{C}$. There was no growth below $10^{\circ} \mathrm{C}$, but inoculums started rooting in the media above $5^{\circ} \mathrm{C}$. At $15^{\circ} \mathrm{C}$, brownish mycelia growth was observed which looked like a brownish cotton ball, with a diameter of $0.3 \mathrm{~cm}$. At $35^{\circ} \mathrm{C}$, the colony was small with a diameter of $0.4 \mathrm{~cm}$ without sporulation and there was no growth at $40^{\circ} \mathrm{C}$. In vitro effect of temperature has been studied by others. Researchers found that temperature range tolerance limit of $A$. alternata was $20-30^{\circ} \mathrm{C}$. The cardinal temperature of fungi have been studied by different investigators on Entomophthora exitialis, E. coronata, E. virulenta and E. aphidis with optimal temperature being 24, 27-33, 30 and 21-24 respectively (Getzin, 1961). Similar results with fungi were obtained by others. (Table 4) Mycelia growth decreased after $30-35^{\circ} \mathrm{C}$, and was maximum at $26-28^{\circ} \mathrm{C}$ (Ajmal et al., 2016).

\section{Effect of different levels of relative humidity (RH) on growth of $A$. alternata}

It is not only the temperature which influences the growth and sporulation of fungi but also factors like light, chemical composition of the substrate, micro and macro environmental humidity and the interaction of these factors in the ecological complex that influence the development of fungal pathogen. Humidity undoubtedly plays a role in sporulation of the fungi. The present isolate of $A$. alternata was capable to grow and sporulate at different levels of $\mathrm{RH}$. The fungus attained its best growth and sporulation at 95 and $100 \% \mathrm{RH}$, with colony diameter measuring 2.6 and $2.9 \mathrm{~cm}$, respectively. At 53\% $\mathrm{RH}$ the colony diameter was $1.6 \mathrm{~cm}$ with moderate sporulation, and at 75 and $85 \% \mathrm{RH}$, it was 1.8 and 2.0 centimeters, respectively with good sporulation. The colony characteristic at alternative humidites were similar except that the fungal growth was highly powdery in the sporulating fungus at 95 and $100 \%$ $\mathrm{RH}$ where it was 1.8 and 2.0 centimeters respectively with good sporulation. The colony characteristic at alternative humidity was similar except that fungal growth was highly powdery in the sporulating fungus at 95 and $100 \% \mathrm{RH}$. With the increase in relative humidity, the growth and sporulation of the fungus also increased. Although $100 \%$ RH supported excellent sporulation with spore count calculation $1.45 \times 10^{5}$ spores $/ \mathrm{ml}$, it was also good at lower values of $\mathrm{RH}$.

The minimal time required for sporulation in saturated atmosphere was found to be 3 days. Lower humidity levels had some sort of retarding effect on the growth and sporulation. Similar results were obtained by others. At $100 \mathrm{RH}$, spores developed within 4 days but required 5 days or longer at 92.5$98 \%$ RH. A.alternata sporulated with $\mathrm{RH}$ as low as $53 \%$ which proved its superiority over other isolates. [Table 5]

\section{Acknowledgement}

We are grateful to Shri S.N. Vijyawargia, Chancellor, and Ms Megha Vijaywargia, Director HR, People's University, Bhopal MP, India for providing research facilities and encouragement in carrying out this project. The authors are also thankful to Sarvajanik Jankalyan Parmarthik Nyas (SJPN), Bhopal MP, India for providing research grant.

\section{References}

Ajmal, M.A., Ara, A., Akhund, S., Nayyar, B.G., Seerat, W. 2016. Stem 
Hishtopathology of sesame seedlings infected with Alternaria alternate. Microscopy, Res., 4: 11-19.

Balai Laxman Prasad, Ahir, R. 2013. Role of temperature and relative humidity on Mycelial growth of Alternaria alternata infecting Brinjal. Trends in Biosci., 6(3): 307-08.

Deshmukh, A.N. 1998. Studies on leaf spot and fruit rot of chilli caused by Alternaria alternata (Fr.) Keissler. M.Sc. (Agri.) Thesis submitted to Mahatam Phule Krishi Vidya Peeth M.P.K.V., Rahur.

Ferron, P. 1978. Biological control of insect pests by entomogenous fungi, anti inflammatory activity. Rev. Entomol., 23: 409-42.

Gaikwad, B.S. 1987. Studies on fruit root and leaf spot of ber (Zizyphus mauritiana L.) caused by Alternaria alternate (Fr.) Keissler. M.Sc. (Agri.) Thesis submitted to M.P.K.V., Rahur.

Getzin, L.W. 1961. Spicaria rileyi (Farlow) Charles, an entomogenous fungus on
Trichoplusiani (Hubner). J. Insec. Pathol., 3: 2-10.

Hege, Y.R., Keshgond, R., Chavan, T. 2015. Efficacy of fungicides against Alternaria alternate infecting Jatropha curcas. Global J. Res. Anal., 4(7): 39899.

Sandhu, S.S. 1995. Effect of Physical factors on germination of entomopathogenic fungus Beauveria bassiana conidia. Proc. Nat. Acad. Sci. Lett., 18(1\&2): 1-5.

Sharma, M., Ghosh, R., Pande, S. 2013. Occurrence of Alternaria alternata causing Alternaria blight in pigeonpea in India. Adv. Biosci. Biotechnol., 4: 702-05.

Shrikant, B., Jadhav, D.S., Patil, B.Y., Chavan, A. 2014. Fungal disease of Alternaria alternate associated with soyabean (Glycine max (L) Merr) and its biological control by efficient plant extract. Indian J. Appl. Res., 4(11): 7981.

\section{How to cite this article:}

Prabhat Kumar Mishra and Vijay Thawani. 2016. Characterization of Alternaria alternata Isolated from Calotropis gigantea Plant Leaf. Int.J.Curr.Microbiol.App.Sci. 5(10): 459-466. doi: http://dx.doi.org/10.20546/ijcmas.2016.510.052 